\title{
Italian bank crisis: flexible application of BRRD rules, or a bailout in disguise?
}

\author{
Jan Famfollet, Eliška Sankotová ${ }^{1}$
}

\begin{abstract}
The economic and financial crisis of the year 2008 highlighted the need for banking sector regulation via the creation of the banking union. The Bank Recovery and Resolution Directive (BRRD) represents an important milestone in the formation of the banking union. It is supposed inter alia to replace the existing practice of bailing out failing banks by the opposite principle of bail-in, which makes the bank recapitalized from the internal resources at the detriment of investors and creditors. However, the Italian solution of handling its failing banks took advantage of existing loopholes in the new regulatory system. Eventually, it went against the spirit of the new rules by deploying taxpayers' money to deal with the banks' failure. This article evaluates the Italian approach and contemplates the adequacy of the new rules-based system by comparing its potentially beneficial room for flexibility with alleged malfunction and unreliability. Finally, it discusses the potential impact of the Italian approach on the further process of completing the banking union, in particular the establishment of its last pillar, the common deposit guarantee scheme.
\end{abstract}

Keywords: banking union, banking supervision, BRRD, bail-in, bailout, precautionary recapitalisation, non-performing loans, Italian banking sector

JEL Classification: G18, G33, G38

Received: 26 November 2019 / Accepted: 9 April 2020 / Sent for Publication: 09 June 2020

\section{Introduction}

The cost of resolving bank crises and rescuing banks in the European Union (EU) was enormous. It is estimated that the financial assistance provided by the governments to the financial sector amounted up to $€ 2$ trillion between 2008 and 2014, which is equivalent to $14 \%$ of the EU GDP in 2014 (European Commission 2016a). The effort to restrict the government aid financed through taxpayers' money is thus easy to understand. Therefore, in June 2012, a decision was made to create a banking union by applying the rules valid for banks of eurozone countries and possibly other EU countries interested in participating (European Commission 2015a). The main objectives of the banking union

\footnotetext{
${ }^{1} \mathrm{Ph}$. D. students at the Department of World Economy, Faculty of International Relations, University of Economics, Prague, Czech republic, famj00@vse.cz, xstre13@vse.cz.
}

(C) 2020 by the authors; licensee Review of Economic Perspectives / Národohospodářský obzor, Masaryk University, Faculty of Economics and Administration, Brno, Czech Republic. This article is an open access article distributed under the terms and conditions of the Creative Commons Attribution 3.0 license, Attribution - Non Commercial - No Derivatives. 
are to establish common supervision of significant banks and a common management of banking crises, regardless of the country in which the bank is located. In particular, the rules are intended to guarantee an orderly resolution of banks deemed "too big to fail", or lead to outright liquidation if the banks do not meet the public interest test.

The EU-wide Bank Recovery and Resolution Directive (BRRD), which entered into force at the beginning of 2015 (while its crucial bail-in provisions in 2016), became an important milestone, or rather cornerstone in the setting up of the banking union. The main purpose of this directive is to limit the state aid to failing banks through bailouts and to replace it by bail-in, potentially accompanied by other resolution tools. This directive has recently been applied in several banking crises across the euro area with different outcomes. That it is due to the fact that many of the recent cases began to be resolved already before the BRRD or before all its relevant provisions were applicable. The treatment of bank failures in Cyprus, Austria, Greece, or Italia has been peculiar by nature as it represented a mix of national approaches combined with a partial application of the BRRD. However, the Italian case of June 2017 stands out from the others as it is one of the first since all the BRRD provisions, including those introducing bail-in, became effective. Thus, the handling of the concerned Italian banks can be viewed as a test for the new European regulation and crisis management structure.

From a more systemic perspective, this paper's focus on Italy and its banking sector follows from its specificity and importance in the EU, and thus in the euro area. Although the banking sectors of Portugal or Ireland may be among those with similar problems, they can hardly be compared in terms of the overall dimensions. On the other hand, compared to other major banking sectors such as Germany, Italian banks have entirely different problems. While German banks like Deutsche Bank predominantly deal with problems arising from financial derivatives losses, the main problem of Italian banks is the non-performing debt. The Italian share of non-performing loans (NPLs) was with $10 \%$ in June 2018 the fourth highest in the EU compared to Greece (45\%), Cyprus (34 \%), and Portugal (12\%) (EBA 2018). Although Italy has only the fourth place in terms of the NPLs ratio, the total amount of overdue claims of its banking sector ( $€ 160$ billion) is reliably the largest in the EU. A possible banking crisis in the Italian banking system, that can potentially be triggered by the failure of large regional banks, could cause far-reaching problems of a systemic nature (Toronto-Dominion Bank 2017). It can have a vastly negative impact on both other euro area countries and the common currency (Stefancic 2017).

The aim of the following text is to outline the basic rules, pillars and governance of the current state of the banking union and, on the example of the recent treatment of Italian banks' crisis, to evaluate the functioning of the existing rules from an economic and legal perspective, and outline possible further development of the banking union.

The first chapter is a legal introduction to the functioning of the banking union. It describes the single rulebook consisting of the set of regulations and directives and the three main pillars of the banking union. These include the Single Supervisory Mechanism, the Single Resolution Mechanism, and the European Deposit Insurance Scheme, whose creation is currently uncertain. The next part of the first chapter focuses on the specific resolution procedure based on the BRRD. 
The second chapter presents an example of a banking crisis solution in the Veneto region in Italia based on the BRRD and banking union rules. It further explains how the Italian specificity, where the bond and shareholders of Italian banks are largely households and retail, led to the search for a different solution than the new European rules for dealing with banking crises foresee.

The third chapter offers different interpretations for the solution used in the case of Italian banks bankruptcy, points out the problematic aspects of the existing rules, and suggests possible further development in banking union rules.

\section{Legal introduction to the functioning of the banking union}

\section{The single rulebook and the main pillars of the banking union}

The single set of rules for the supervision of credit institutions (the so-called Single Rulebook) represents the basis of the banking union, which is common to all EU Member States. The main objective of these rules is to prevent banking crises, to establish rules for a common solution for failing banks, to set capital requirements, and to protect depositors (European Commission 2015a).

The Capital Requirements Directive (CRD IV) ${ }^{2}$ and the Capital Requirements Regulation (CRR), ${ }^{3}$ which have been in force since 1 January 2014 in all EU Member States represent the key legislative documents for the unification of rules and supervision of financial institutions. These regulations implement the international Basel III rules into the European law and establish a bank's minimum amount of capital that leads to its safe operation on the market, allowing for its management of losses and better absorbing economic shocks.

The fundamental rules also include the Deposit Guarantee Schemes Directive (DGSD), ${ }^{4}$ which unifies the rules set by the deposit limit of up to $€ 100000$ per one depositor and bank, and the BRRD ${ }^{5}$. BRRD regulates the way of resolving failing banks or banks in difficulties preventing financial instability, without the help of public funds.

\footnotetext{
${ }^{2}$ Directive 2013/36/EU of the European Parliament and of the Council of 26 June 2013 on access to the activity of credit institutions and the prudential supervision of credit institutions and investment firms, amending Directive 2002/87/EC and repealing Directives 2006/48/EC and 2006/49/EC

${ }^{3}$ Regulation (EU) No 575/2013 of the European Parliament and of the Council of 26 June 2013 on prudential requirements for credit institutions and investment firms and amending Regulation (EU) No 648/2012

${ }^{4}$ Directive 2014/49/EU of the European Parliament and of the Council of 16 April 2014 on deposit guarantee schemes (recast)

5 Directive 2014/59/EU of the European Parliament and of the Council of 15 May 2014 establishing a framework for the recovery and resolution of credit institutions and investment firms and amending Council Directive 82/891/EEC, and Directives 2001/24/EC, 2002/47/EC, 2004/25/EC, 2005/56/EC, 2007/36/EC, 2011/35/EU, 2012/30/EU and 2013/36/EU, and Regulations (EU) No 1093/2010 and (EU) No 648/2012, of the European Parliament and of the Council
} 
On the single set of EU-wide rules, the two fundamental pillars of the banking union are based - the Single Supervisory Mechanism and the Single Resolution Mechanism. Eurozone countries are compulsory to participate in these mechanisms, while the other EU Member States may join these two mechanisms voluntarily. It is done through the institute of "close cooperation" of non-euro area countries with the ECB. Although this solution does not guarantee a participation of the countries outside euro area on an equal footing to those in, but represents a fairly compromise option in terms of legislation (Ferran 2014). It provides specific compensation mechanisms and safeguards, including the one to leave the banking union in case of substantial disagreement with the decision taken by the ECB Governing Council (where the non-euro area countries are not represented).

The Single Supervisory Mechanism (SSM), which has been in place since 4 November 2014, constitutes a banking supervision system by the European Central Bank (ECB) in cooperation with individual national supervisory authorities, or more accurately with National Competent Authorities (NCAs). In addition to supervision, SSM focuses on ensuring the security, reliability, and stability of the banking sector, which is supposed to lead to greater financial integration. Currently (2019), the ECB directly supervises $114^{6}$ Significant Institutions (SIs), ${ }^{7}$ which account for almost $82 \%$ of banking assets in the euro area. Less Significant Institutions (LSIs), thus the banks with indirect ECB supervision, are directly supervised by NCAs, but still in cooperation with the ECB to ensure consistency and high standards of supervision (European Central Bank 2018). The ECB may give instructions and recommendations to NCAs and may also assume direct supervision of any minor bank if it finds sufficient reasons to do so. The SSM is regulated primarily by EU Regulation No. 1024/2013, ${ }^{8}$ EU Regulation No. 468/2014, ${ }^{9}$

\footnotetext{
${ }^{6}$ State of play for the first quarter of 2019. In 2014 there were 120 major banking groups, i.e. approximately 1200 banking institutions and 3500 less significant banking institutions (European Central Bank 2014).

${ }^{7}$ According to SSM Regulation No. 1024/2013, an institution is considered significant if: (i) the total value of its assets exceeds $€ 30$ billion; (ii) the total value of its assets relative to the country's GDP exceeds $20 \%$ (if this value is simultaneously not less than $€ 5$ billion); (iii) the ECB confirms the significant position of the institution by notifying the relevant NCA considering the institution of significant relevance. Furthermore, the ECB may consider an institution to be significant due to its cross-border activities. An institution that is the subject of ESM or EFSF financial assistance (whether received or only in the application status) is also considered significant. Last but not least, a significant institution can be an institution that is one of the three most significant credit institutions in the country.

${ }^{8}$ Council regulation (EU) No 1024/2013 of 15 October 2013 conferring specific tasks on the European Central Bank concerning policies relating to the prudential supervision of credit institutions

${ }^{9}$ Regulation (EU) No 468/2014 of the European Central Bank of 16 April 2014 establishing the framework for cooperation within the Single Supervisory Mechanism between the European Central Bank and national competent authorities and with national designated authorities (SSM Framework Regulation) (ECB/2014/17)
} 
EU Regulation No. 1022/2013, ${ }^{10}$ and others (European Commission 2016a; European Central Bank 2017).

The quite high flexibility of the ECB's intervention in NCAs' supervision over LSIs was also confirmed by the Court of Justice of the European Union (CJEU) in May 2017 in the case of Landeskreditbank Baden-Württemberg - Förderbank vs. European Central Bank. ${ }^{11}$ This flexibility may also imply some degree of uncertainty for NCAs, which the ECB has tried to eliminate by issuing internal criteria for overtaking direct supervision over LSIs, but these are not exhaustive and do not reflect, for example, banking crisis management developments (European Commission 2017a).

Ioannidou (2012) stresses that the ECB's intense cooperation with national authorities within an integrated system avoids "unnecessary centralisation of powers, duplication of structures and the loss of knowledge on the local economies". During the financial crisis, national supervisors proved to be problematic due to the own national interests, and their actions led to concealing the real state of affairs, postponing corrective measures, and thus to much greater losses. However, others point out that if troubled banks in a given country are less significant, the SSM may not provide timely and adequate solutions as the ECB may not be sufficiently informed about the problems and will depend on the quality of the information provided by the NCAs (Ferran 2014).

Improved supervision of cross-border institutions as well as earlier detection of systemic risk within the EU banking system seem to be apparent benefits of the SSM. However, concerns have been raised about a possible conflict of interest inherent in the dual-task of the ECB, i.e., pursuing both price and financial system's stability objectives. The ECB may be concerned about the implementation of monetary policy targets that are countercyclical, while supervisory policy can be pro-cyclical because of the measures required to improve the situation of the institutions. Or the other way around, the aim to tame asset bubbles in the financial sector may be overrun by a monetary policy decision aiming to increase inflation and boost growth, thus fuelling the pro-cyclicity in the financial sector. However, Issing (2003) argues that in most cases price stability supports financial stability and therefore these two objectives are not contradictory; only in rare cases can there be a short-term conflict in which it is also optimal to deviate from the inflation target in the short term in order to achieve price stability in the medium term. But the conflict should disappear with an appropriate definition of price and financial stability and, in particular, the time horizon to which the objectives refer (Issing 2003). Also, it is the supervision of banking institutions that is supposed to help obtain better data and improve forecasting and thus contribute to better monetary policy implementation (Ioannidou 2012).

\footnotetext{
${ }^{10}$ Regulation (EU) No 1022/2013 of the European Parliament and of the Council of 22 October 2013 amending Regulation (EU) No 1093/2010 establishing a European Supervisory Authority (European Banking Authority) as regards the conferral of specific tasks on the European Central Bank pursuant to Council Regulation (EU) No 1024/2013

${ }^{11}$ Case T-122/15, Judgment of the General Court (Fourth Chamber, Extended Composition) of 16 May 2017 Landeskreditbank Baden-Württemberg - Förderbank v European Central Bank, par 24.
} 
According to Wyplosz (2012) the selection of the ECB as the main supervisor of the banking sector is determined by the need for a lender of last resort. Within the euro area, this function can be performed only by the ECB, which is able to dispose of large amounts of money in a relatively short time. Logically enough, the ECB should be responsible for overseeing the euro area banking sector as it is responsible for maintaining the overall financial stability and the euro.

Based on the EU Regulation No. 806/2014 (also the SRM Regulation, SRMR), ${ }^{12}$ and following the SSM, the second pillar of the banking union, the Single Resolution Mechanism (SRM) has been established. The Single Resolution Board (SRB), set up at the beginning of 2015 and fully operational since 2016, was put in charge of ensuring proper management of significant banks' failures, with minimal impact on both the real economy and the public finances. Similarly to the NCAs, at the Member States level, the National Resolution Authorities (NRAs) operate, the establishment of which is required by Article 3 of the BRRD. However, in the context of SRM, NRAs de facto only execute SRB instructions on the implementation of crisis management. ${ }^{13}$

In case the bank is failing or likely to fail (FOLTF), ${ }^{14}$ and there is no other private solution, and a special treatment is in the public interest, then SRB proposes a bank restructuring process. This process, set out in a resolution scheme, may consist of using one or a combination of multiple resolution tools defined in the BRRD. The prerequisite is that the situation is managed without taxpayers' money, and losses are primarily borne by shareholders and private creditors of the bank.

Furthermore, EU Regulation No. 806/2014 establishes the Single Resolution Fund (SRF). Funding from the SRF should be used only in exceptional cases where the distribution of losses between shareholders and creditors of the bank is not sufficient and only to support the resolution tools. By 31 December 2023, the size of the Fund should be at least $1 \%$ of the volume of covered deposits of all credit institutions in the banking union, which is typically estimated at around $€ 55$ billion (European Commission 2015b). ${ }^{15}$ Currently (2019), about 3186 institutions contribute to the fund, and on 17 July 2019, the Fund amounted to almost $€ 33$ billion (Single Resolution Board 2019).

Regarding the discretionary powers of the SRB, Alexander (2015) points out that issues may be raised relating to the Meroni case law, ${ }^{16}$ which puts strict limits on the delegation of powers to the EU agencies. Although the SRM legislation dealt with the limits

\footnotetext{
${ }^{12}$ Regulation (EU) No 806/2014 of the European Parliament and of the Council of 15 July 2014 establishing uniform rules and a uniform procedure for the resolution of credit institutions and certain investment firms in the framework of a Single Resolution Mechanism and a Single Resolution Fund and amending Regulation (EU) No 1093/2010

${ }^{13}$ See e. g. recital 91 of SRMR.

${ }^{14}$ The FOLTF is decided by the ECB or, under certain conditions by the SRB.

${ }^{15}$ However, SRB chairman Elke König stated in June 2018 that by 2023 she expects an increase in SRF volume to $€ 60$ billion (Reuters 2018).

${ }^{16}$ Meroni \& Co., Industrie Metallurgiche, SpA v High Authority of the European Coal and Steel Community. Case 9-56. Judgment of the Court of 13 June 1958.
} 
imposed by the Meroni doctrine by involving the Commission and the Council in the decision-making process, the preparatory and recommendatory mandate of the SRB may still seem to have too large room for judgement as it lacks clearly defined criteria for assessing banks' resolvability or making recommendations regarding the use of resolution tools. Given the weight that will likely be given by the Commission and the Council to such recommendations, it may lead to accusations of violation of the respective case law and may have to be submitted for judicial review.

The potential third pillar of the banking union should be created in the form of the European Deposit Insurance Scheme (EDIS). This pillar is supposed to build on the DGSD, which regulates national deposit guarantee schemes and should eliminate negative impacts of the potential strong local shocks to the country's banking sector. As a result, EDIS should increase depositors' confidence in banks regardless of the country in which the banks are located (European Commission 2016b). This should be ensured by introducing rules which will weaken the link between the banks and the country in which they are located and share risk across the participating states. The central point of EDIS is therefore the common Deposit Insurance Fund (DIF), which would cover the liquidity shortfall of the national guarantee funds and possibly also losses depending on the final form of the whole mechanism, which may eventually differ from the original Commission proposal of November 2015.

The introduction of EDIS was proposed and highlighted already in the Five Presidents' Report of June 2015. This document considered a priority, above all, to start negotiations on the common deposit insurance (not its final completion) already in the first phase of deepening the economic and monetary union (EMU), which is in the first half of 2017 (European Commission 2015c). This ambition has not been realized. Due to the reluctance of the so-called northern flank of the EU Member States, political negotiations on EDIS have not yet been launched by the end of 2019. Sufficient risk reduction in the financial sector is required first, according to the ECOFIN conclusions of 17 June 2016, the so-called Roadmap 2016 (Council of the EU 2016). The Commission Discussion Paper on EMU Deepening of May 2017, therefore, proposed adoption of EDIS by 2019 with full implementation by 2025 at the latest. The Communication of the European Commission (2017b) on completing the banking union of October 2017 subsequently came up with some ideas on modifying the EDIS design (see more below) so that it was more acceptable to critics to unblock the debate between the Member States and to allow a compromise on EDIS in 2018 but to no avail.

The importance of introducing such a system is also emphasized in the context of efforts to limit the strong link between the banking sector and the public finances of a given Member State (so-called sovereign-bank nexus), ${ }^{17}$ resulting i.a. (or perhaps primarily)

\footnotetext{
${ }^{17}$ This phenomenon, in the recent crisis, have given rise to a vicious circle, where the deteriorating public finances as a result of the financial crisis have a negative impact on the value of government bonds leading to losses for their investors, i.e. banks. Subsequent public aid to the ailing banks further deepens the public sector deficit/debt, which leads to a further decrease in the value of bonds and increased losses of banks leading to further need of bailouts. In other countries, the cycle began with bank losses, then continued as described.
} 
from holding large volumes of sovereign government debt by many eurozone banks. This issue of sovereign exposures represents another related challenge seen by many as complimentary to EDIS (Véron 2017) and thus invites possible revision of the regulatory framework.

In terms of financing, according to the original proposal, ${ }^{18}$ the EDIS system should be managed by the SRB and the pay-outs of insured deposits in case of bank failure should be covered by DIF. The DIF should then be fiscal neutral in the medium term, similarly to the SRF model, be built up from contributions ${ }^{19}$ paid by banks participating in the banking union, and their level depends on the banks' risk profile. According to the original proposal, EDIS should be introduced in the following three phases: (1) the reinsurance phase where EDIS provides limited funding for the first three years in case of liquidity shortfall and covers part of the losses of the participating deposit guarantee scheme (DGS); (2) the co-insurance phase in which the share of liquidity assistance and loss coverage of participating DGS would gradually increase over the next four years; (3) the full insurance phase.

On 11 October 2017, the Commission issued the above-mentioned Communication on completing the banking union (European Commission 2017b), in which it came up with ideas that could facilitate a possible agreement among the Member States on EDIS. These ideas, which are deliberately presented as no formal proposal, consist mainly of a gradual phasing-in of the EDIS and conditionality of the transition between phases (implementation of certain conditions in terms of risk reduction and targeted asset quality review). The first phase could only take the form of partial repayable liquidity support to the national DGS in need, which runs out of funds to pay out deposit claims.

\section{Rescue procedure and resolution of failing banks}

BRRD and SRMR represent uniform rules for resolving failing banks through restructuring, with minimal impact on public finances. The BRRD, which applies to all EU Member States, has seen difficulties already during transposition into national law; the deadline for implementation (beginning of 2015) ${ }^{20}$ was not met by 11 EU Member States and six of them were subsequently brought before the CJEU (European Commission 2015c; 2015d). Currently, the BRRD is already implemented in the national regulations of all EU Member States (European Commission 2017c). The SRMR, which only applies to banking union members, was adopted in April 2014. Some particulars relating to SRM financing are dealt with in the form of the Intergovernmental Agreement on the transfer and mutualisation of contributions to the SRF (the so-called IGA). ${ }^{21}$ As of 1

\footnotetext{
${ }^{18}$ Proposal for a Regulation of the European Parliament and of the Council of 24. 11. 2015 amending Regulation (EU) 806/2014 in order to establish a European Deposit Insurance Scheme, ${ }^{19}$ The gradual increase in contributions to EDIS would be accompanied by a proportional reduction in contributions to the national DGS, the financing of which will be fully replaced by EDIS over time.

${ }^{20}$ The application of bail-in tool was postponed by another year.

${ }^{21}$ All EU Member States except the UK and Sweden have signed the IGA.
} 
January 2016, the IGA was ratified by all countries participating in the banking union (i.e., the eurozone countries), so the SRM could become fully effective on the same date.

The BRRD in Article 32 (Conditions for resolution) and the SRMR as mirrored in Article 18 (Resolution procedure) define three basic cases in which the resolution authority initiates a resolution process for the bank. These are (i) when the institution is failing or likely to fail (FOLTF), (ii) where there are no alternative measures by the private sector or supervisors to restore the bank's viability and (iii) where the resolution action is necessary for the public interest, that is especially where the liquidation of the bank under national insolvency proceedings would not lead to the intended objectives.

Article 34 of the BRRD sets out the general principles governing resolution. As mentioned above, the loss is borne first by the shareholders of the institution, followed by its creditors in accordance with the order of priority of their claims under national law. ${ }^{22}$ Furthermore, the senior management of the institution is replaced (not if such a move would hinder the achievement of the intended objective), and the new one is obliged to cooperate to achieve the resolution objectives. Full protection applies to all covered deposits, i.e., up to $€ 100000$ according to the DGSD, and losses imposed on the creditors must not be higher than they would have been in normal insolvency proceedings (the so-called no creditor worse off principle, NCWO). In cases where losses can no longer be passed on to other creditors (for example due to reaching the level of covered deposits on the liability side of the balance sheet) the resolution fund (Single Resolution Fund, SRF) filled with contributions from the banking sector may in exceptional cases be used. This is subject to the bank's prior absorption of losses and internal recapitalization (write-off and conversion) of at least $8 \%$ of all liabilities, including the capital. The total financial assistance from the Fund is limited to $5 \%$ of all liabilities, including the bank's capital.

BRRD further establishes four basic resolution tools. The first, the Sale of Business Tool, allows resolution authorities to transfer without shareholder permission, either shares and other instruments of ownership or assets, liabilities, and rights to a purchaser that is not a bridge institution. The Sale of Business Tool was used by the Commission decision of 7 June 2017, when all shares and equity instruments of Banco Popular Español S.A. were transferred on the acquiring Banco Santander S.A., and this was the first resolution case carried out under the responsibility of the SRB. The Bank was assessed as FOLTF due to the problematic liquidity situation (Single Resolution Board 2017a).

In the case of the transfer of the above-mentioned instruments to a bridge institution, the second tool, the Bridge Institution Tool, is used. A legal entity owned by one or more public authorities, controlled by the resolution authority, created to carry out the institution's original activity in whole or in part is considered a bridge institution.

Where the assets, liabilities, and rights of a banking institution are transferred to one or more asset management vehicles (AMVs), the so-called Asset Separation Tool is used.

\footnotetext{
22 The hierarchy of bank creditors in insolvency had varied across Member States. As of December 27. 2017, BRRD2 in Article 108 partially harmonises the hierarchy of creditors in the EU.
} 
An AMV that can accept all or part of the assets, liabilities, and rights is defined in a similar way to the bridge institution. This instrument is also known as "bad bank".

The last instrument is the Bail-in Tool that represents the write-off and conversion of the banking institution's liabilities, as defined in Article 43 of the BRRD. This instrument is used if the purpose of the resolution is to recapitalize the institution and to allow it to continue to carry out the activities with sufficient market confidence, or where the purpose is to convert to equity or reduce the principal amount of liabilities transferred to the bridge institution (with the aim to provide it with the capital), or to a new buyer/AMV through relevant resolution tools. The bail-in mechanism replaces the previously (in the last crisis period) used bailout tool, which represents an external, i.e., public (government) rescue of the institution with the related impact on public finance/taxpayers.

The BRRD also recognizes the possibility of so-called precautionary recapitalization, ${ }^{23}$ that is, an exceptional situation where extraordinary public financial support is required and which is consisting of the equity instruments purchase or capital injections due to a possible future capital shortfall identified in the adverse stress test scenario ${ }^{24}$ (European Central Bank 2016). Precautionary recapitalization must be carried out in the interest of maintaining financial stability where there is a serious disruption of the economy and endorsed by the Commission (Directorate-General for Competition, DG COMP) for the state aid control. However, the approval of precautionary recapitalization does not activate the resolution of a given banking entity, as this situation is exempt from FOLTF qualification. It can only be granted to solvent banks that meet minimum capital requirements. The resulting state aid is temporary, limited only to the reported shortcomings from the adverse scenario eliminating unlikely losses, not already incurred or probable losses (European Commission 2017c).

Extraordinary public financial support, which may be provided by the competent ministry or the government in close cooperation with the resolution authority, is governed by Article 56 of the BRRD. However, this is the very last possibility in the crisis management process, where even the above-mentioned tools cannot achieve the intended objectives. Such government financial stabilization instruments include the public equity support tool and the temporary public ownership tool. However, here too, the condition of at least $8 \%$ of total liabilities as a contribution of shareholders and creditors, and the condition of compliance with the EU state aid framework (i.e., approval by the DG COMP), apply.

\section{The banking crises resolution on the example of Italy}

The situation in the Italian banking sector has been unfavourable for a long time. Despite government measures taken, "the Italian banking sector still lags behind other euro area banking systems and ranks close to the bottom with regard to the main sol-

\footnotetext{
${ }^{23}$ BRRD, Article 32, paragraph 4, point d) iii).

${ }^{24}$ According to the baseline scenario, the bank does not face a capital shortfall.
} 
vency indicators", which may put the euro area banking sector as a whole at risk (European Commission 2017d). The overall decline in confidence in the Italian banking sector was reflected in 2016, mainly in the sharp fall in the Italian banks' stock prices. The sector suffers from insufficient capital buffers, high NPLs ${ }^{25}$ and a limited banks' ability to absorb such losses, as well as the outlook for weak economic growth coupled with low profitability, structural weaknesses, high operation costs or shortcomings in senior management.

The high share of NPLs in EU countries is gradually declining, as evidenced by a weighted average decline from $6.5 \%$ in December 2014 (EBA 2018), to 5,4 \% in June 2016, to 4,5\% in July 2017 (EBA 2017) and to 3,6\% in the second quarter of 2018 (EBA 2018). However, the differences between countries are striking; and what matters is not only the absolute amount of NPLs but also their distribution within smaller/larger and more/less capitalized banks (Navaretti, Calzolari, Pozzolo 2017). Due to the interconnectedness of individual EU Member States, even the countries with low (relative) NPLs can affect the stability of the whole euro area.

Chyba! Nenalezen zdroj odkazů. shows a gradual but not yet sufficient improvement over the years, both in terms of total and, in particular, Italian lending by banks under the supervision by the ECB (SSM). In terms of the NPLs composition, according to the Bank of Italy as of 31 May 2016, $€ 200$ billion of the total $€ 360$ billion was considered "bad loans", i.e., those with a high probability of default (Ministero dell' Economia e delle Finanze 2016). Currently, the credit quality is improving due to economic recovery, and the NPLs are also falling. As of Q2 2019, the NPLs ratio was $8 \%$, i.e., half compared to 2016. However, despite the reforms undertaken and the relative reduction of the NPLs ratio so far, the present level still represents one of the highest numbers in the EU and poses risks not only to the Italian banking sector.

Since the end of 2015, some Italian banks have undergone both private and public interventions in crisis management. Also, various rescue instruments have been created. These are the alternative investment fund Atlante providing primarily the required scarce capital or the Atlante II fund specializing in liquidation of impaired loans (European Commission 2017c; Ministero dell' Economia e delle Finanze 2016).

The Atlante Fund has already been used for a $€ 2.5$ billion capital increase in the case of two Venetian banks Banco Popolare di Vicenza S.p.A and Veneto Banca S.p.A in 2016, followed by a further $€ 0.9$ billion in recapitalization (European Commission 2017c). In addition, a system of government guarantees for the securitization of impaired GACS assets was created to help banks get rid of troubled assets. ${ }^{26}$

\footnotetext{
${ }^{25}$ According to the definition of EBA (adopted by Commission Implementing Regulation No $680 / 2014)$, non-performing exposures are those that are more than 90 days past due or, irrespective of the amount or number of days past due, are considered unlikely to be fully reimbursed by the borrower without calling the collateral. The current definition of non-performing exposures is newly to be found also as part of the CRR.

${ }^{26}$ Garanzia Cartolarizzazione Sofferenze (GACS) is an Italian public guarantee scheme approved by the European Commission designed to support the securitization and removal of NPLs from
} 
Table 1. NPLs to total loans and advances to banks under ECB supervision in $€$ billion

\begin{tabular}{|c|c|c|c|c|c|c|}
\hline & \multicolumn{2}{|c|}{$\begin{array}{c}\text { Loans and advances, } \\
€ \text { billion }\end{array}$} & \multicolumn{2}{|c|}{$\begin{array}{c}\text { NPLs and advances, } € \\
\text { billion }\end{array}$} & \multicolumn{2}{|c|}{ NPLs ratio, \% } \\
\hline & $\begin{array}{c}\text { ECB } \\
\text { Supervision }\end{array}$ & Italy & $\begin{array}{c}\text { ECB } \\
\text { Supervision }\end{array}$ & Italy & $\begin{array}{c}\text { ECB } \\
\text { Supervision }\end{array}$ & Italy \\
\hline $\begin{array}{l}\text { Q1 } 2016 \\
(30.6 .2016)\end{array}$ & 13877,89 & - & 950,83 & - & $6,85 \%$ & - \\
\hline $\begin{array}{l}\text { Q2 } 2016 \\
(15.10 .2016)\end{array}$ & 14163,79 & 1663,12 & 936,67 & 271,32 & $6,61 \%$ & $16,31 \%$ \\
\hline $\begin{array}{l}\text { Q3 2016 } \\
(31.12 .2016) \\
\end{array}$ & 14183,82 & 1664,43 & 921,02 & 270,34 & $6,49 \%$ & $16,24 \%$ \\
\hline $\begin{array}{l}\text { Q4 } 2016 \\
(31.3 .2017)\end{array}$ & 14255,26 & 1638,81 & 879,09 & 248,48 & $6,17 \%$ & $15,16 \%$ \\
\hline $\begin{array}{l}\text { Q1 } 2017 \\
(30.6 .2017)\end{array}$ & 14617,44 & 1685,90 & 865,01 & 249,35 & $5,92 \%$ & $14,79 \%$ \\
\hline $\begin{array}{l}\text { Q2 } 2017 \\
(30.9 .2017)\end{array}$ & 14516,86 & 1662,56 & 794,91 & 199,71 & $5,48 \%$ & $12,01 \%$ \\
\hline $\begin{array}{l}\text { Q3 } 2017 \\
(31.12 .2017)\end{array}$ & 14728,39 & 1653,98 & 759,1 & 195,97 & $5,15 \%$ & $11,85 \%$ \\
\hline $\begin{array}{l}\text { Q4 } 2017 \\
(7.4 .2018) \\
\end{array}$ & 14651,75 & 1677,56 & 721,18 & 186,72 & $4,92 \%$ & $11,13 \%$ \\
\hline $\begin{array}{l}\text { Q1 } 2018 \\
(30.6 .2018)\end{array}$ & 14313,17 & 1665,90 & 688,01 & 179,55 & $4,81 \%$ & $10,78 \%$ \\
\hline $\begin{array}{l}\text { Q2 } 2018 \\
(30.9 .2018)\end{array}$ & 14934,56 & 1633,92 & 657,15 & 158,97 & $4,40 \%$ & $9,73 \%$ \\
\hline $\begin{array}{l}\text { Q3 } 2018 \\
(31.12 .2018)\end{array}$ & 15058,10 & 1639,76 & 627,70 & 153,36 & $4,17 \%$ & $9,35 \%$ \\
\hline $\begin{array}{l}\text { Q4 2018 } \\
(18.3 .2019)\end{array}$ & 15228,07 & 1629,53 & 579,32 & 134,65 & $3,80 \%$ & $8,26 \%$ \\
\hline $\begin{array}{l}\text { Q1 } 2019 \\
(19.6 .2019)\end{array}$ & 15967,77 & 1774,37 & 586,69 & 148,46 & $3,67 \%$ & $8,37 \%$ \\
\hline $\begin{array}{l}\text { Q2 } 2019 \\
(17.9 .2019) \\
\end{array}$ & 15767,04 & 1757,27 & 561,78 & 140,83 & $3,56 \%$ & $8,01 \%$ \\
\hline
\end{tabular}

Source: (European Central Bank 2019)

Through preventive recapitalization, banks are also to be assisted by an Italian government-approved $€ 20$ billion fund, which, however, should be accompanied by significant consolidation and further reforms in the banking sector. The reason for creating such fund was the request of the Italy's fourth largest bank Monte dei Paschi di Siena for preventive recapitalization due to the failure of its own recapitalization plan in December 2016 (European Commission 2017c). State aid approval of $€ 5.4$ billion under preventive recapitalization was confirmed by the Commission in July 2017 after the bank was declared to be solvent by the ECB and investors (subordinated bondholders and shareholders) committed to bear the share of the losses, i.e., to apply the "burden sharing" of $€ 4.3$ billion. The restructuring plan foresees an NPLs write-off of $€ 26.1$ billion using instruments such as the Atlante II or GACS (European Commission 2017e).

the banks' balance sheets. 
The above-mentioned Banca Popolare di Vicenza and Veneto Banca, operating in the Venetian region of Italy, proved to be problematic, characterized by high operating costs and high NPLs ratios of 37\%, compared to the Italian average of $18 \%$ at that time (European Commission 2017f). These banks have been identified by the ECB as FOLTF due to repeated violations of capital requirements. SRB subsequently assessed the fulfillment of the conditions for launching resolution measures and in June 2017 concluded that there was insufficient reason to initiate the resolution procedure - both banks met only two of the three requirements for initiating resolution:

Both banks were assessed as failing (FOLTF) due to their non-compliance with the capital adequacy rules and violations of the rules in the conduct of their business. Also, there were no private sector or supervisory measures to prevent these banks from failing, with an emphasis on the bank's inability to raise additional private capital, the absence of business plans or their insufficiency and the inefficiency of using write-down and conversion of equity instruments leading to loss reduction (Single Resolution Board 2017b). It was precisely the absence of private resources to cover the losses, the participation of which was required by the Commission, which made it impossible to use preventive recapitalization (Italian Banking Association 2017), as was the case with the aforementioned Monte dei Paschi di Siena.

The justification by the SRB for not initiating the resolution procedure for the failing banks was based primarily on the poor links between these banks and the remaining financial sector. Assistance to these banks was not considered to be of public interest as it would not have remedied a serious disturbance in the Member State economy under Article 107 (3) b) TFEU. According to the SRB, these banks were to be liquidated under Italian national law, as their liquidation under standard insolvency proceedings was not expected to have a major impact on financial stability in the euro area (Single Resolution Board 2017b).

Although both banks were considered insignificant by the SRB in the context of the impact on the euro area banking sector, the Italian proposal for their liquidation emphasized the significant position of the banks in the particular region, and the State aid approval was requested from the Commission. In the case of the banking sector, the State aid is governed by a special framework constituted by the Commission's 2013 Banking Communication, which "exceptionally allows for aid to remedy a serious disturbance in the economy of a Member State" (European Commission 2013), thus taking over the substance of Article 107 TFEU (see above). An important condition, in this case, was, according to Article 15 of the Banking Communication, the so-called cost-sharing, where "the bank and its capital holders should contribute to the restructuring as much as possible with their own resources. State support should be granted on terms which represent an adequate burden-sharing by those who invested in the bank", insured deposits being protected under the above rules and the DGSD.

In accordance with these rules, the Commission gave its consent to the use of State aid for the liquidation of the Venetian banks and their partial integration into the Intesa 
Sanpaolo group. ${ }^{27}$ The Commission determined the Italian state aid measures do not constitute aid to Intesa, because it was selected after an open, fair and transparent sales process. On the other hand, the measures constitute aid for the two liquidated banks to the extent that these residual entities continue any economic activity. It is, therefore, up to the Italian state to ensure their activities will be limited to the minimum. Furthermore, the shareholders and junior creditors have fully contributed, reducing the costs to the Italian State (European Commission 2017f).

The measures aimed at "facilitating the banks' market exit" by the Italian State were set at $€ 4,785$ billion and then at around $€ 12$ billion in the form of state guarantees. Owing to losses borne by the shareholders, total costs were reduced, and approximately $€ 18$ billion of the NPLs were erased, which contributed to the consolidation of the Italian banking sector (European Commission 2017f). According to the Italian Banking Association (2017), such a method of rescuing banks can be considered to be in full compliance with European law, to the extent permitted, appropriate to the situation. The Association literally states: "The use of state funds, which have a good chance of being recovered, should be viewed in this instance as a necessary response to specific market failures, but as exceptional, also in view of the underlying principles of the new European rules" (Italian Banking Association 2017). In the chapter below, a closer look will be taken at whether the chosen procedure was indeed adequate and entirely in accordance with the rules and spirit of the European legislation.

\section{The impact of the "Italian solution" on the future of the banking union}

The case of the aforementioned Italian banks is a symptom of the very troubled banking sector of Italy, which, unlike Spain or Ireland, has not managed to be cleaned up before the introduction of the common rules. Solution found in the described examples ${ }^{28}$ should thus have been a pragmatic step in a situation where the relevant bond holders were, for the most part, households and small businesses. Bailing in "ordinary people" appeared to be, for obvious reasons, politically and socially unacceptable. ${ }^{29}$ The new acquirer of parts of the Venetian banks Intesa Sanpaolo thus used part of the money provided by the Italian government to compensate subordinate bond holders and, in the case of Monte dei Paschi di Siena, part of the state aid went to compensate ordinary Italians to whom the bank sold subordinated debt (Coppola 2017). This phenomenon of

\footnotetext{
${ }^{27}$ The state aid decision SA.45664 - Orderly liquidation of Banca Popolare di Vicenza and Veneto Banca - Liquidation aid. Adopted on 25 June 2017.

${ }^{28}$ Banca Popolare di Vicenza and Veneto Banca were liquidated with public funds injected in favour of the new acquirer of remaining parts of the businesses, the Intesa Sanpaolo; The Monte dei Paschi di Siena was preventively recapitalized under Article 32 (4) (d) point iii) of the BRRD I Article 18 (4) (d) SRMR.

${ }^{29}$ The impact on retail in the event of the write-off of senior bonds and large deposits would be similar to a failure of depositor protection under the DGSD, i.e. politically difficult to bear. This can be illustrated by the example of the liquidation of four Italian credit cooperatives ('popolari banks') in December 2015, when one pensioner committed suicide after losses were imposed on small bondholders (Coppola 2017).
} 
'mis-selling' appears to be one of the other structural problems of the Italian banking sector and the result of lax surveillance prior to the introduction of central supervision at the banking union level and may have also been a key factor behind authorizing the State aid.

The successful solution to the situation in the Spanish (but also Irish) banking sector before the entry into force of the new rules consisted mainly in the comprehensive consolidation and recapitalization undertaken to isolate bad assets. Such an in-depth cleanup of the banking sector had not been done in Italy before the new framework came into effect, which is mainly to blame for the Italian government's inability or unwillingness to undertake the necessary structural reforms. However, this can also be seen as a negative consequence of the too rapid adoption of legislation prohibiting State aid before some banking sectors have been adequately cleaned up, moreover in a situation where all the prerequisites for the successful implementation of the new bail-in framework have not been met; e.g., setting a minimum requirement for own funds and eligible liabilities (MREL) and MREL compliance, or availability of resolution plans for all banks.

The use of public funds on examples of liquidation of Venetian banks, as well as the preventive recapitalization of the MPS, can, therefore, be assessed from two different perspectives. According to the first, the existing banking union rules so far do not work in practice as the use of public support to handle the bank crisis at the national level contradicts the spirit of these new rules. The exemptions in the granting of aid were therefore used somewhat cunningly, albeit in accordance with clearly defined conditions of the European Commission (Banking Communication 2013) and Article 107 TFEU, ${ }^{30}$ thus not according to the general rules based on the BRRD, which are not identical to those under Article 107 TFEU and the Banking Communication 2013.

The other view of the resolution of the Italian banks stresses the flexibility and importance of decision-making at the national level. In this view, the banking union is a flexible system that leaves room to reflect local specificities. In addition, Beck (2017) argues that the central solution would lack a sense of local specifics and, in particular, that the domestic political representation would be responsible for the possible negative effects of a transnational decision. According to Beck, such an approach can perhaps be afforded only in the case of a banking group with a cross-border systemic impact, where the need for a central arbitrator is evident.

However, in line with the first view, it is possible to point out a number of specific weaknesses in the current framework, which have enabled its targeted use by the actors involved to carry out measures forbidden by default. First and foremost, the complexity of the system made it possible, in the Italian case, to find a solution which, at the outset, undermines confidence in the new rules. Although it is not legally possible to speak of a violation of the rules or arbitrariness of the European Commission, as for example,

\footnotetext{
${ }^{30}$ The Banking Communication 2013 (based on Article 107 TFEU) as a whole is a temporary exception to the general rule that State aid is incompatible with the functioning of the internal market - see Article 6 of the Communication.
} 
preventive recapitalization (MPS) is a measure foreseen by the BRRD, its use may give rise to expectations that this instrument - intended by the legislator as exceptional henceforth will become a standard solution with the Commission's eyes closed. This creates a reputation problem in terms of the so-called "repeated game". Likewise, the government's compensation to the new acquirer of parts of the liquidated Venetian banks approved by the Commission on the basis of the argument on the significant position of banks in the region calls into question both the SRB's decision not to apply the resolution procedure (due to the insignificant impact on the euro area) and the framework within which small banks are supposed to be liquidated without the use of public funds.

Reichlin a Vallée (2016), in line with the second view, support a pragmatic/flexible approach by proposing three steps necessary to stabilize the current dysfunctional Italian banking sector. The strengthened Atlante Fund, which is sort of a bad bank, should play a key role in the restructuring of the rather weak Italian banks towards the selection of the bad assets. After eliminating the pressing problem with NPLs, the second phase is to carry out the bail-in with the consequent compensation of retail investors. The final phase of the recovery of the banking sector should be the consolidation based on profound reforms of the banks' overall business model, leading to their renewed profitability.

It is important to note that, as a result of the current banking union rules, these recovery plans for the whole banking sector of a given country cannot be holistically designed and implemented from the EU level as part of the banking sectors (the LSIs) remain under NCAs' supervision. This specific double-track system also contributes greatly to the complexity of the system in which the outcomes of the application of the rules are difficult to predict. At the same time, the SRB does not have executive powers to implement decisions at the national level (the implementation is the responsibility of the NRAs) and also cannot provide the necessary related reform steps in the remaining banking sector. The new framework of banking union rules, thus deprives certain powers of national authorities and transfers them to the European level along with strict conditions of use (Reichlin, Vallée 2016). Therefore, individual steps to reform the entire banking sector must be taken particularly by the relevant EU Member States on their initiative.

Another line of argument relating to the adequacy of setting up a resolution framework in interaction with the insolvency framework may be based on the fact that the banking union still lacks the key components that would make it considered complete and thus fully operational.

One set of initiatives contributing to the completion of the banking union could focus on gaining more from possible further improvements in the crisis management framework. The Italian case had shown that there may be loopholes that generate unexpected outcomes such as involving public funds in national liquidation when it was not possible to get the desired support through European resolution. The existence of blind spots in the current framework has also manifested itself by another case, the Latvian bank ABLV, where FOLTF had been declared, and the European resolution has not been initiated by the SRB, unlike in the case of the Venetian banks. But the conditions for liquidation have not been met either at the national level, so the bank has found itself in a "standstill 
situation" (or "limbo"). It has eventually been liquidated voluntarily. Developments such as these make a strong case for further harmonisation of the bank insolvency procedures. Indeed, the insolvency procedures in the Member States differ substantially, whether in the process (administrative or judicial), available tools, or measures. There are also still partially different hierarchies of claims. However, it is questionable whether such improvements leading to further harmonisation of triggers and procedures could be considered a completion of the banking union.

The completion of the banking union remains one of the key officially declared steps towards completing the European Economic and Monetary Union (European Commission 2015e). Specific proposals aim to increase risk-sharing, in particular through the introduction of a common backstop to the SRF and of the EDIS, the final design of which is not yet decided. It is the absence of the last pillar of the banking union in the form of a common deposit protection that can create a strong implicit pressure on the government of a particular state to intervene in a bank crisis (Beck 2017) with public funds to maintain their functioning and protect households' savings. Apart from the Italian case where bank bond holders are largely retail clients, the liquidation of a bank may conceivably, i.a. due to the DGSD rules, trigger demand for compensation of an amount that the capacity of the national DGS will not be able to handle (compared to a common pool).

However, a number of Member States currently demands sufficient risk reduction in the banking sectors before such risks can be shared through other common schemes (as is clear from the 2016 Roadmap). These countries form one of the two opinion groups that, in general, favours compliance and enforcement accompanied by sanctions, in particular the application of bail-in and risk reduction in the banking sectors. On the other hand, the second opinion group of Member States supports the establishment of common risksharing mechanisms and greater freedom and flexibility in applying the rules.

However, the introduction of the fully-fledged EDIS in terms of full coverage of losses by the common central fund is unlikely not only because of the current political unwillingness of the "northern league" in the EU, but also potentially undesirable as long as the strong link exists between banks and their home sovereign in the form of holding large volumes of domestic government bonds by banks in the respective state (due to the so-called home bias phenomenon). The main problem may not be the very presence of government debt in the banks' balance sheets, but a high concentration (Véron 2017) that reinforces the doom loop between bank and sovereign risk and creates incentives for government bailouts, thus creating the potential to trigger a crisis spiral. While the latter group may welcome the flexible application of the new rules and possibly take advantage of it, the former one may want to ensure the "Italian approach" never to happen again.

The argument for maintaining the status quo and, thus, also against the regulation of sovereign exposures (or regulatory treatment of sovereign exposures - RTSE) tends to refer to the role of the domestic banking sectors in absorbing shocks during stress periods on the government bond markets (Visco 2016). Removing this role can also lead to negative fiscal implications, as Coeuré (2016) explains. Despite these arguments, sufficient portfolio diversification or an overall reduction in government bonds volume in the euro area bank balance sheets through greater pressure on financial institutions to 
adequately assess the sovereign default risk appears logical. Indeed, implementing EDIS without solving the home bias problem would allow the system to be exploited through the possible informal governments' pressure (especially by governments in financial difficulty) on domestic banks to purchase unlimited amounts of their debt using EDISprotected deposits - which is rightly seen as an indirect form of guarantees for the financing of national governments (Véron 2017).

Moreover, accepting the argument of banks as a contingency liquidity buffer for their governments (possibly operating in the short term) would also deny the main objective of the banking union, namely to break the above-mentioned structural destabilizing link between sovereign and banking risk. Besides theoretical arguments, the "peripheral" Member States are justifiably concerned about the possible decline in demand for their own government bonds and its redirection to the bonds of more fiscally responsible Member States, and as a result, increase their financing costs. Market turbulence in response to the ending of the regulatory benefits associated with government bonds is also possible. However, these arguments should not prevent the system from being adjusted in the long term in principle (Weidmann 2013). Still, it should be acknowledged that the RTSE issue creates a number of practical problems and may have farreaching implications, especially if such a framework were implemented independently of the coordinated action on the global level (in the Basel Committee on Banking Supervision).

However, full completion of the banking union is not only a matter of launching the last pillar (with or without RTSE). In a broader context, a completed banking union can be seen as a fully-fledged single banking market but requires a much more comprehensive set of reforms. Such reforms would have to target the elimination of distortions arising from various forms of banking regulation, taxation, accounting, auditing, insolvency law (for both banks and clients), pension systems, housing finance systems, etc. (Schnabel, Véron 2018). These impediments indeed appear to be much more important in considering a truly consolidated single banking market than just quick regulatory fixes in the crisis management framework. Of course, greater objectives require a different level of political commitment, which is not easy to get in the current political debate where different interests compete for the future shape of the banking environment and of the broader economic and financial framework in the EU.

Gros (2017) points out there are three main actors that have a significant influence on further shaping the rules of the banking union; Germany, France, and Italy. The German vision of the functioning of the banking union is based on risk reduction first. That means a reduction in the concentration of government bonds in banks' balance sheets, eliminating the negative effects of the generous fiscal policies of the euro area countries, and only then risk-sharing through EDIS can be acceptable. On the contrary, Italy is not in favour of dealing with the high concentration of government bonds (typical of the Italian banking sector) due to concerns about the increased cost of funding its own debt, thus favouring EDIS without preconditions. France's course in the debate on the future 
rules of the banking union is currently less clear, although it rather supports the positions typical of the euro area's southern flank. ${ }^{31}$

From a more political perspective, the case of the resolution of the Italian banks has also shown that possibly thanks to the importance of its economy, Italy may be able to achieve a flexible application of the rules to its advantage. The question then is whether even smaller countries could achieve such a favourable approach in real political practice. At the same time, the specific treatment of the Italian case may not benefit Italian interest after all in the long term as the perceived bending of the rules may be alarming to further process of shaping the future rules and mechanisms. In the forthcoming debates on the completion of the banking union, Italy may play a role of deterrent and provide a pretext for the myriad safeguards in the system against potential abuses, thus making the system rigid and difficult to deploy when actually needed. Specifically, on EDIS, the experience of the Italian approach, together with the assumption that Italy and other peripheral countries may be the net beneficiaries of such a mechanism, may lead to a common deposit guarantee scheme being introduced only in a limited form, e.g. repayable liquidity provision to the national systems in need, and no loss coverage.

Consequently, the agreement of Germany and France in the context of the overall effort to deepen EMU may be decisive for the further direction of the banking union. The joint Franco-German Declaration of 19 June 2018, the so-called Meseberg Declaration (The Press and Information Office of the Federal Government 2018), outlining what steps should be included in the new roadmap to reduce and (subsequently) share risks, was to offer the seeds of a possible compromise between the two strongest euro-area Member States. On EDIS, however, the commitment was rather disappointing, and there is no tangible output of the promised preparatory work yet (2019). The Meseberg Declaration only confirmed that the differences in perception of need and possible design of EDIS, as well as the related need to regulate sovereign exposures or to introduce a new class of safe assets, are still too large to be bridged by a concrete agreement to complete the banking union. Only the main features of the common backstop to the SRF have been agreed in the document, the parameters of which were subsequently approved by the European Council in a similar vein. This facility is intended, among other things, to replace the Direct Recapitalization Instrument (DRI) of the ESM and step in with a common quasi-fiscal (in the medium-term fiscally neutral) capacity when SRF gets depleted. Both countries also endorsed the idea of introducing a common budget for the euro area, which is intended to promote competitiveness, convergence, and stabilization in the euro area as of 2021. Despite the vagueness and caution in the wording of the Declaration Some (e.g. Véron) point out that German Chancellor Merkel accepted EDIS as a goal in principle for the first time and that a number of other issues also show at least some shift in the previously much more cautious German position.

\footnotetext{
${ }^{31}$ While, in general terms, the view of French President Emmanuel Macron emphasizes greater centralization of the monetary union and the need to create its own finance and budget minister for the euro area, the German side puts more emphasis on national accountability of euro area member countries (Eichengreen 2017).
} 
This shift in the German position was confirmed by yet another proposal; a position paper coming out of the Federal Ministry of Finance in November 2019 followed by a shortened version in the article in Financial Times published by minister Olaf Scholz. Both publications endorse the idea of EDIS and announce Germany is ready to move forward with key banking union projects (Scholz 2019). According to the German nonpaper, the banking union needs to be completed and market fragmentation overcome to create a more integrated and efficient market that will help cross-border investments, increase growth potential and private risk sharing, which is all necessary to reduce Europe's competitive disadvantage at international level. Allegedly, this vision requires better conditions for the use of capital and liquidity by cross-border banks, as well as the introduction of a common deposit insurance scheme. However, this is conditional on reducing and keeping risks low. This should be achieved by streamlining the resolution regime and harmonizing insolvency legislation. There is also a need for adequate regulation of government bonds and reduction of non-performing loans (NPLs). A completed banking union must also remove opportunities for tax arbitrage, where some countries attract banks with more favourable tax rules at the expense of other Member States (BMF 2019).

While these proposals seem ambitious, it is apparent the German minister sets out conditions that will not be easy to meet, especially by the troubled Member States of the southern flank. It is also not yet clear whether this position paper indeed reflects the position of the Federal government and if it eventually gains its support. However, this opaque situation may also be a test by the government to see the limits of what is bearable for the German general and professional public, which has long been stuck in a defensive position. Therefore, the reaction will show how far a minister can go if willing to carry on with the banking union reforms.

This apparent shift in the German position may be read as demonstrating some recognition that the requirement to complete the banking union, albeit in a minimalist version (i.e., not involving the completion of the single market in banking), is legitimate and logical, after appropriate risk reduction, as it represents a solution to curb the tendency to seek national solutions to banking crises through rescues with using public funds, and in combination with RTSE to eliminate the main direct channels of risk and crisis transfer between banks and states. A definitive end to using state aid for addressing local specificities in the context of failures of systemically less significant institutions could be brought by a revision of the EU state aid framework, through which the European Commission will have to react sooner or later to changing economic conditions in the EU.

\section{Conclusion}

The creation of the banking union framework in response to the financial crisis is an important element in building a more comprehensive and deeper economic and monetary union. The current rules were created primarily to protect taxpayers' money, with potential bank losses to be borne by the bank's shareholders and creditors in the future. Other equally important principles of the banking union project are reversing the trend of financial fragmentation and the home bias, protecting financial stability and strength- 
ening confidence in the European financial system as a whole, in an effort to break the doom loop between banks and sovereigns.

The Italian solution to bank failures and subsequent liquidation with public support, however, raises the question of whether it was in line with the spirit of banking union rules and whether the flexibility applied did not call these rules into question, when the imperative of national interest once again led to the use of public funds that should have been forbidden by the new rules except for exceptional cases. However, it is clear that even under the currently defined rules, public support may be used in exceptional circumstances in the case of the preventive recapitalization tool under the BRRD and in accordance with the 2013 Banking Communication.

The solution found in the case of the Italian banks points out, inter alia, the different levels of banking regulation, where the rules are laid down at international level in the form of Basel III rules, at the national level and EU level, creating a complex system and new difficulties. As a result of the application of the existing banking union rules on the Italian example, a pragmatic and most acceptable solution for a particular Member State was found. Future developments will show whether this was the first and only case followed by stricter rules and enforcement, or an important precedent for future looser practice and using loopholes in the system. The answer to this question will be clearer in the further process of completing the banking union, coupled with sufficient risk reduction in the EU banking sectors, firstly in the form of the common deposit insurance and the possible regulatory treatment of sovereign exposures. Secondly, in the context of the more distant objective of completing the single banking market, which includes a much more comprehensive set of reforms, in particular the harmonization of taxation, customer protection, labour or insolvency law.

In the meantime, quick gains could be achieved by closing loopholes and blind spots in the current resolution framework i.a. by harmonising triggers, conditions and main features of the bank insolvency procedures at the national level. For the proper functioning of the BRRD as intended, preventive recapitalization should remain a true exception and not a regularly used tool; this could be helped by a better definition of what a "solvent institution" means. A clearer definition of the "public interest" and ensuring its consistency across several levels of European legislation would also be warranted. Further consolidation of the proper functioning of the current banking resolution framework may be brought about by the discretionary action of the Commission, specifically by aligning the state aid framework with the BRRD. Such a move should be facilitated by the ongoing overall improvement of conditions in the financial sector and the economy.

Disclosure statement: No potential conflict of interest was reported by the authors.

\section{References}

ALEXANDER, K., (2015). European Banking Union: A Legal and Institutional Analysis of the Single Supervisory Mechanism and the Single Resolution Mechanism. European law review. 1 April 2015. Vol. 40, p. 154-187. 
BECK, T,, (2017). The European banking union at three: A toddler with tantrums. VoxEU.org [online]. 4 July 2017. [Accessed 24 August 2017]. Available from: http://voxeu.org/article/european-banking-union-three

BMF, (2019). Position paper on the goals of the banking union [online]. 2019. [Accessed 22 November 2019]. Available from: http://prod-upp-image-read.ft.com/b750c7e4ffba-11e9-b7bc-f3fa4e77dd47

CASE T-122/15, JUDGMENT OF THE GENERAL COURT (FOURTH CHAMBER, EXTENDED COMPOSITION) OF 16 MAY 2017 LANDESKREDITBANK BADENWÜRTTEMBERG - FÖRDERBANK V EUROPEAN CENTRAL BANK, PAR 24.

COEURÉ, B., (2016). Sovereign debt in the euro area: too safe or too risky? European Central Bank [online]. 3 November 2016. [Accessed 15 July 2018]. Available from: https://www.ecb.europa.eu/press/key/date/2016/html/sp161103.en.html

CONSOLIDATED VERSION OF THE TREATY ON THE FUNCTIONING OF THE EUROPEAN UNION.

COPPOLA, F., (2017). Italy's Latest Bank Bailout Has Created A Two-Speed Eurozone. Forbes [online]. 6 2017. [Accessed 19 August 2018]. Available from: https://www.forbes.com/sites/francescoppola/2017/06/26/italys-latest-bank-bailout-hascreated-a-two-speed-eurozone/\#450ed85844a4

COUNCIL OF THE EU, (2016). Council Conclusions on a roadmap to complete the Banking Union. Consilium [online]. 17 June 2016. [Accessed 15 July 2018]. Available from: http://www.consilium.europa.eu/en/press/press-releases/2016/06/17/conclusionson-banking-union/

DIRECTIVE 2014/59/EU OF THE EUROPEAN PARLIAMENT AND OF THE COUNCIL of 15 May 2014 establishing a framework for the recovery and resolution of credit institutions and investment firms and amending Council Directive 82/891/EEC, and Directives 2001/24/EC, 2002/47/EC, 2004/25/EC, 2005/56/EC, 2007/36/EC, 2011/35/EU, 2012/30/EU and 2013/36/EU, and Regulations (EU) No 1093/2010 and (EU) No 648/2012, of the European Parliament and of the Council.

EBA, (2017). Risk Assessment Of The European Banking System. November 2017. [online]. Luxembourg: Publications Office of the European Union. [Accessed 10 March 2018]. ISBN 978-92-9245-386-2. Available from: www.eba.europa.eu/documents/10180/2037825/Risk+Assessment+Report++ November+2017.pdf

EBA, (2018). Risk Assessment Of The European Banking System. December 2018. [online]. Luxembourg: Publications Office of the European Union. [Accessed 10 January 2019]. ISBN 978-92-9245-492-0. Available from: https://eba.europa.eu/documents/10180/2518651/Risk_Assessment_Report_December_ 2018.pdf

EICHENGREEN, B, (2017). Can Macron and Merkel agree on how to fix the eurozone? The Guardian [online]. 11 September 2017. [Accessed 23 September 2017]. Available 
from: http://www.theguardian.com/business/2017/sep/11/macron-merkel-eurozonefrance-germany

EUROPEAN CENTRAL BANK, (2014). Guide to banking supervision. November 2014. [online]. Frankfurt am Main. [Accessed 29 July 2017]. ISBN 978-92-899-1414-7. Available

from: https://www.bankingsupervision.europa.eu/ecb/pub/pdf/ssmguidebankingsupervision20 1411.en.pdf?807838fa2a8bb958749f411c432d1f3e

EUROPEAN CENTRAL BANK, (2016). What is a precautionary recapitalisation and how does it work? European Central Bank - Banking Supervision [online]. 27 December 2016. [Accessed 22 August 2017]. Available from: https://www.bankingsupervision.europa.eu/about/ssmexplained/html/precautionary_rec apitalisation.en.html

EUROPEAN CENTRAL BANK, (2017). Regulatory environment. European Central Bank - Banking Supervision [online]. 2017. [Accessed 11 August 2017]. Available from: https://www.bankingsupervision.europa.eu/legalframework/regulatory/html/index.en.ht $\mathrm{ml}$

EUROPEAN CENTRAL BANK, (2018). Single Supervisory Mechanism. European Central Bank - Banking Supervision [online]. 2018. [Accessed 24 November 2018]. Available from: https://www.bankingsupervision.europa.eu/about/thessm/html/index.en.html

EUROPEAN CENTRAL BANK, (2019). Supervisory Banking Statistics - First quarter 2016-Second quarter 2019. Media \& Publications [online]. 2019. Available from: https://www.bankingsupervision.europa.eu/press/publications/date/2019/html/index.en. html

EUROPEAN COMMISSION, (2013). Communication from the Commission on the application, from 1 August 2013, of State aid rules to support measures in favour of banks in the context of the financial crisis ("Banking Communication") [online]. [Accessed 14 August 2017]. Available from: https://eur-lex.europa.eu/legalcontent/EN/TXT/PDF/?uri=CELEX:52013XC0730(01)\&from=EN

EUROPEAN COMMISSION, (2015a). Updated version of first memo published on 15/04/2014 - Banking Union: restoring financial stability in the Eurozone. [online]. 4 November 2015. [Accessed 10 August 2017]. Available from: http://europa.eu/rapid/press-release_MEMO-15-6164_en.htm?locale=en

EUROPEAN COMMISSION, (2015b). Communication from the Commission to the European Parliament, the Council, the European Central Bank, the European Economic and Social Committee and the Committee of the Regions "Towards the completion of the Banking Union”. [online]. Štrasburk. [Accessed 3 August 2017]. Available from: https://eur-lex.europa.eu/legalcontent/EN/TXT/PDF/?uri=CELEX:52015DC0587\&from=EN

EUROPEAN COMMISSION, (2015c). Commission refers six Member States to the Court of Justice of the EU for failing to transpose EU rules on Bank Recovery and Re- 
solution. [online]. 22 October 2015. [Accessed 12 August 2017]. Available from: http://europa.eu/rapid/press-release_IP-15-5827_en.htm

EUROPEAN COMMISSION, (2015d). Commission requests 11 Member States to apply EU rules on Bank Recovery and Resolution. [online]. 28 May 2015. [Accessed 12 August 2017]. Available from: http://europa.eu/rapid/press-release_IP-155057_en.htm

EUROPEAN COMMISSION, (2015e). Completing Europe's Economic and Monetary Union (The Five Presidents' Report) [online]. [Accessed 20 August 2019]. Available from: https://ec.europa.eu/commission/sites/beta-political/files/5-presidentsreport_en.pdf

EUROPEAN COMMISSION, (2016a). Single supervisory mechanism. European Commission [online]. 4 November 2016. [Accessed 11 August 2017]. Available from: https://ec.europa.eu/info/business-economy-euro/banking-and-finance/bankingunion/single-supervisory-mechanism_en

EUROPEAN COMMISSION, (2016b). European deposit insurance scheme. European Commission [online]. 4 November 2016. [Accessed 10 August 2017]. Available from: https://ec.europa.eu/info/business-economy-euro/banking-and-finance/bankingunion/european-deposit-insurance-scheme_en

EUROPEAN COMMISSION, (2017a). Commission staff working document. Accompanying the document Report from the Commission to the European Parliament and the Council on the Single Supervisory Mechanism established pursuant to Regulation (EU) No 1024/2013 [online]. [Accessed 13 July 2018]. Available from: https://ec.europa.eu/info/sites/info/files/171011-ssm-review-report-staff-workingdocument_en.pdf

EUROPEAN COMMISSION, (2017b). Communication to the European Parliament, the Council, the European Central Bank, the European economic and social committee ande the Committee of the regions on completing the Banking Union [online]. [Accessed 15 July 2018]. Available from: https://eur-lex.europa.eu/legalcontent/EN/TXT/PDF/?uri=CELEX:52017DC0592\&from=EN

EUROPEAN COMMISSION, (2017c). Bank recovery and resolution directive - transposition status. European Commission - European Commission [online]. 13 January 2017. [Accessed 12 August 2017]. Available from: https://ec.europa.eu/info/publications/bank-recovery-and-resolution-directivetransposition-status_en

EUROPEAN COMMISSION, (2017d). Country Report Italy 2017 Including an InDepth Review on the prevention and correction of macroeconomic imbalances [online]. [Accessed 17 August 2017]. Available from: https://ec.europa.eu/info/sites/info/files/2017-european-semester-country-report-italyen_0.pdf

EUROPEAN COMMISSION, (2017e). State aid: Commission authorises precautionary recapitalisation of Italian bank Monte dei Paschi di Siena. [online]. 4 July 2017. [Accessed 24 August 2017]. Available from: http://europa.eu/rapid/press-release_IP-171905_en.htm 
EUROPEAN COMMISSION, (2017f). State aid: Commission approves aid for market exit of Banca Popolare di Vicenza and Veneto Banca under Italian insolvency law, involving sale of some parts to Intesa Sanpaolo. [online]. 25 June 2017. [Accessed 14 August 2017]. Available from: http://europa.eu/rapid/press-release_IP-171791_en.htm

FERRAN, E., (2014). European Banking Union: Imperfect, But It Can Work [online]. [Accessed 14 February 2020]. Available from: https://papers.ssrn.com/abstract=2426247

GROS, D., (2017). Try again to complete the Banking Union! In: Europe's Political Spring: Fixing the Eurozone and Beyond. Edited by Agnès Bénassy-Quéré and Francesco Giavazzi [online]. London: CEPR Press. p. 78. [Accessed 22 September 2017]. ISBN 978-1-912179-03-9. Available from: http://voxeu.org/content/europe-s-politicalspring-fixing-eurozone-and-beyond

IOANNIDOU, V., (2012). A first step towards a banking union. VoxEU.org [online]. 16 October 2012. [Accessed 7 February 2020]. Available from: https://voxeu.org/article/first-step-towards-banking-union

ISSING, O., (2003). Monetary and Financial Stability: Is there a Trade-off? European Central Bank [online]. 28 March 2003. [Accessed 2 March 2020]. Available from: https://www.ecb.europa.eu/press/key/date/2003/html/sp030329.en.html

ITALIAN BANKING ASSOCIATION, (2017). Address by the Governor of the Bank of Italy Ignazio Visco [online]. Rome: Printing and Publishing Division of the Bank of Italy. [Accessed 23 August 2017]. Available from: http://www.bis.org/review/r170731d.pdf

MERONI \& CO., INDUSTRIE METALLURGICHE, SPA V HIGH AUTHORITY OF THE EUROPEAN COAL AND STEEL COMMUNITY. CASE 9-56. JUDGMENT OF THE COURT OF 13 JUNE 1958.

MINISTERO DELL' ECONOMIA E DELLE FINANZE, (2016). Italian Banking Sector: Recent Developments And Reforms [online]. [Accessed 18 August 2017]. Available

from:

http://www.tesoro.it/focus/sistema_bancario/ITALIAN_BANKING_SECTOR.pdf

NAVARETTI, G. B., CALZOLARI, G., POZZOLO, A., (2017). Getting rid of nonperforming loans in Europe. VoxEU.org [online]. 6 July 2017. [Accessed 24 August 2017]. Available from: http://voxeu.org/article/getting-rid-nonperforming-loans-europe

REGULATION (EU) No 806/2014 OF THE EUROPEAN PARLIAMENT AND OF THE COUNCIL of 15 July 2014 establishing uniform rules and a uniform procedure for the resolution of credit institutions and certain investment firms in the framework of a Single Resolution Mechanism and a Single Resolution Fund and amending Regulation (EU) No 1093/2010.

REICHLIN, L., VALLÉE, S., (2016). Resolving Europe's Banking Crisis in Italy. Project Syndicate [online]. 14 October 2016. [Accessed 24 August 2017]. Available from: 
https://www.project-syndicate.org/commentary/europe-italy-flawed-banking-union-bylucrezia-reichlin-and-shahin-vallee-2016-10?barrier=accessreg

REUTERS, (2018). Backstop for EU bank fund to be set up soon: SRB chair. [online]. 10 June 2018. [Accessed 13 July 2018]. Available from: https://www.reuters.com/article/us-banks-eu-funds/backstop-for-eu-bank-fund-to-beset-up-soon-srb-chair-idUSKBN1J60ZE

SCHNABEL, I., VÉRON, N., (2018). Completing Europe's Banking Union Means Breaking the Bank-Sovereign Vicious Circle. PIIE [online]. 14 May 2018. [Accessed 19 August 2018]. Available from: https://piie.com/blogs/realtime-economic-issueswatch/completing-europes-banking-union-means-breaking-bank-sovereign

SCHOLZ, O., (2019). Germany will consider EU-wide bank deposit reinsurance. Financial Times [online]. 5 November 2019. [Accessed 24 November 2019]. Available from: https://www.ft.com/content/82624c98-ff14-11e9-a530-16c6c29e70ca

SINGLE RESOLUTION BOARD, (2017a). The Single Resolution Board adopts resolution decision for Banco Popular [online]. [Accessed 12 August 2017]. Available from: https://srb.europa.eu/en/node/315

SINGLE RESOLUTION BOARD, (2017b). The SRB will not take resolution action in relation to Banca Popolare di Vicenza and Veneto Banca. [online]. 23 June 2017. [Accessed 12 August 2017]. Available from: https://srb.europa.eu/en/node/341

SINGLE RESOLUTION BOARD, (2019). SRF grows to $€ 33$ billion after latest round of transfers. Single Resolution Board [online]. 17 July 2019. [Accessed 18 July 2019]. Available from: https://srb.europa.eu/en/node/804

STEFANCIC, Mitja, (2017). Troubles of the italian banking system and the smothered hopes of Europe. Review of Innovation and Competitiveness. 2017. Vol. 3, no. 2, p. 99116.

THE PRESS AND INFORMATION OFFICE OF THE FEDERAL GOVERNMENT, (2018). Meseberg Declaration. Bundesregierung [online]. 19 June 2018. [Accessed 19 August 2018].

Available

from:

https://www.bundesregierung.de/Content/EN/Pressemitteilungen/BPA/2018/2018-06-

19-meseberg-declaration.html?nn=709674

THE STATE AID DECISION SA.45664 - ORDERLY LIQUIDATION OF BANCA POPOLARE DI VICENZA AND VENE-TO BANCA - LIQUIDATION AID. ADOPTED ON 25 JUNE 2017.

TORONTO-DOMINION BANK, (2017). More needs to be done to restore viability to Italy's banking sector [online]. [Accessed 19 August 2017]. Available from: https://www.td.com/document/PDF/economics/special/ItalianBanks2017.pdf

VÉRON, N., (2017). Sovereign Concentration Charges: A New Regime for Banks' Sovereign Exposures [online]. [Accessed 15 July 2018]. ISBN 978-92-846-1999-3. Available from: http://bruegel.org/wpcontent/uploads/2017/11/IPOL_STU2017602111_EN.pdf 
VISCO, I., (2016). Banks' sovereign exposures and the feedback loop between banks and their sovereigns [online]. [Accessed 19 August 2018]. Available from: https://www.bis.org/review/r160509a.pdf

WEIDMANN, J., (2013). Stop encouraging banks to buy government debt. Financial Times [online]. 30 September 2013. [Accessed 19 August 2018]. Available from: https://www.ft.com/content/81a505a4-278c-11e3-8feb-00144feab7de

WYPLOSZ, Ch., (2012). On banking union, speak the truth. VoxEU.org [online]. 17 September 2012. [Accessed 7 February 2020]. Available from: https://voxeu.org/article/banking-union-speak-truth 